\title{
Smart City dalam Memenuhi Hak-Hak Penyandang Difabel di Yogyakarta "Studi Kasus : Infrastruktur Transportasi Publik dalam Memenuhi Hak Penyandang difabel"
}

\author{
Muhammad Ibnu Hiban'1), Eko Priyo Purnomo'), Aulia Nurkasiwi ${ }^{3)}$ \\ ${ }^{12) 33}$ Ilmu Pemerintahan, Universitas Muhammadiyah Yogyakarta \\ Jl. Brawijaya, Geblagan, Tamantirto, Kec. Kasihan, Bantul, Daerah Istimewa Yogyakarta 55183 \\ Email : muhammadibnuhiban@gmail.com ${ }^{1)}$, eko@umy.ac.id ${ }^{2)}$, aulianurkasiwi@gmail.com $^{3)}$
}

\begin{abstract}
The research method used is descriptive qualitative, according to researchers more suitable to use this study because it is more effective in finding the answers listed in the formulation of the problem. The author also takes references from previous studies that have examined this matter for a long time, but this study is different from previous studies. the results of this study are the concept of smart city is a new inovation to help government services, with the use of technology, information and communication. One of them is public transportation, which is a mode of transportation launched by the government to facilitate public services. Trans Jogja is a mode of transportation launched by the Yogyakarta city government to facilitate its people in safe, comfortable, safe, affordable and environmentally friendly travel. Trans Jogja in fulfilling disability rights still cannot be said to be fulfilled in using the modes of transportation that have been provided by the government, to fulfill the rights of persons with disabilities the government must improve the bus stop infrastructure used by passengers so as to provide comfort and security for people with disabilities. On the other hand the government is also experiencing obstacles In the development of bus stop improvement, the government is experiencing problems, namely the problem of land ownership that would be used as a stop, so that it is hampered in its development. This problem should be quickly resolved, because it is already regulated in Law No. 2 of 2012 which regulates land acquisition for public use.
\end{abstract}

Keywords : smart city, disability rights

\begin{abstract}
Abstrak
Metode Penelitian yang digunakan bersifat kualitatif deskriptif, menurut peneliti lebih cocok menggunakan penelitian ini karena lebih efektif dalam menemukan jawaban-jawaban yang tertera dalam rumusan masalah. Penulis juga menggambil referensi dari penelitian sebelumnya yang sudah meneliti hal ini dari lama, namun penelitian ini berbeda dengan penelitian sebelumnya. hasil penelitian ini ialah Konsep smart city adalah inovasi baru untuk membantu pelayanan pemerintahan, dengan pemanfaatan teknologi, informasi dan komunikasi. Salah satunya adalah transportasi public, yang merupakan moda transportasi yang di luncurkan oleh pemerintah untuk mempermudah pelayanan public. Trans jogja adalah moda transportasi yang diluncurkan oleh pemerintah kota Yogyakarta untuk mempermudah masyarakatnya dalam perjalanan yang aman, nyaman, amdal, terjangkau dan ramah lingkungan. Trans jogja dalam pemenuhan hak-hak disabilitas masih belum bisa dikatakan terpenuhi dalam menggunakan moda transportasi yang telah disediakan oleh pemerintah, untuk memenuhi hak-hak penyandang disabilitas pemerintah harus memperbaiki infrastruktur halte yang digunakan oleh penumpang sehingga memberikan kenyamanan dan keamanan bagi masyarakat penyandang disabilitas. Disisi lain pemerintah juga mengalami kendala Dalam pengembangan perbaikan halte bus, pemerintah mengalami kendala yaitu masalah kepemilikan lahan yang mau di jadikan halte, sehingga menjadi terhambat dalam pengembangannya. Permasalah ini seharusnya cepat terselesaikan, karena sudah diatur dalam Undang-Undang No 2 tahun 2012 yang mengatur tentang pembebasan lahan untuk kepentingan umum.
\end{abstract}

Kata kunci : smart city, hak-hak difabel 


\section{Pendahuluan}

\section{A. Latar Belakang}

Transportasi public di Yogyakarta adalah moda transportasi yang di lucuncurkan oleh pemerintah kota yogyakarta untuk membantu masyarakatnya dalam melakukan perjalanan dengan nyaman, aman dan terjangkau harganya (Kaledi \& Herwangi, 2019). Dengan adanya transportasi public di kota Yogyakarta di harapkan dapat membantu masyarakatnya dalam melakukan perjalanan.

Transportasi public di kota Yogyakarta sangat penting bagi masyarakat asli maupun pendatang, karena dapat membantu masyarakat asli Yogyakarta maupun pendatang dalam melakukan perjalanan (Ketersediaan, Dan, \& Husein, 2016). Akan tetapi masyarakat penyandang disabilitas masih kesusahan dalam mengakses moda transportasi publik di kota Yogyakarta. Kota Yogyakarta adalah kota yang ramai dengan penduduknya, masyarakat asli maupun pendatang yang sedang menempuh Pendidikan maupun pencari kerja. Dengan hal tersebut berdampak pada pelayanan transportasi public. Masyarakat penyandang difabel yang akan menggunakan transportasi public masih kesulitan karena, insfrastruktur transportasi public yang kurang memadahi bagi masyarakat penyandang disabilitas baik itu masyarakat asli Yogyakarta maupun masyarakat pendatang dengan tujuan wisata, pendidikan maupun mencari kerja.(Rachmawati, Ramadhan, \& Rohmah, 2018).

Smart city adalah sebuah konsep untuk membuat kota inovatif yang memanfaatkan teknologi informasi dan komunikasi dan teknologi lainnya untuk meningkatkan kualitas hidup, efesiensi dari pelaksanaan dan pelayanan kota serta tingkat kompetitif suatu kota sementara mendukung generasi saat ini dan yang akan dating terkait aspek ekonomi, social dan lingkungan. Konsep smart city di Yogyakarta di kembangkan dengan memadukan unsur teknologi, masyarakat dan pemerintahan. Untuk menjadikan kota pintar (smart city). Dalam rangka melakukan terobosan dan percepatan terwujudnya konsep smart city ini, pemerintah kota Yogyakarta memfokuskan pada tiga isu utama yakni smart education, smart tourisme dan smart transportation ( smart mobility) (Gunartin, 2018).

Smart mobility adalah sebuah konsep pengembangan kota sebagai bagian dari konsep smart city yang merupakan konsep pengembangan transportasi berbasiskan pada teknologi informasi dan komunikasi, yang diharapkan melalaui teknologi informasi pelayanan transportasi publik dapat mudah, aman, nyaman, pelayanan yang cepat serta memiliki harga yang terjangkau bagi masyarakat (Benevolo, et al. 2016). Sedangkan menurut Alberti (2011) dalam Pratiwi (2015) Kota cerdas dengan transportasi cerdas akan memberikan kemudahan perjalanan bagi masyarakat kota (citizens) melalui ketersedian sarana transportasi publik yang inovatif, dan berkelanjutan serta dapat memberikan dampak lingkungan yang rendah. Berdasarkan variabel yang dikemukan oleh Giffingger, et al (2007) dan Cohen (2011) terdapat 3 variabel utama pada smart mobility yaitu Aksesibilitas, Ketersediaan teknologi informasi (ITS) dan Integrasi (antar moda dan ITS).

Orang penyandang disabilitas adalah seseorang yang mempunyai kebutuhan khusus yang tidak seperti kebutuhan orang lain. Seperti kebutuhan kursi roda, tongkat buat jalan dan masih banyak lagi. Diskriminasi dialami oleh orang penyandang difabel, seperti pendidikan, politik, social, pekerjaan yang layak, aksesbilitas atau mobilitas yang kurang mendukung dan bentuk-bentuk deskriminitas yang lain (Sugi Rahayu, Dewi, \& Ahdiyana, 2013). Disinilah pentingnya partisipasi pemerintah untuk meningkatkan pelayanan bagi masyarakat penyandang disabilitas.

Dalam hal ini, apakah didalam infastruktur smart mobility sudah mencakup seluruh lapisan masyarakat kota Yogyakarta, dalam artian masyarakat penyandang disabilitas. Oleh karena itu penelitian ini ingin mengetahui di dalam infastrukur smart mobility apakah sud

\section{B. Rumusan Masalah}

Adapun rumusan masalah dalam penelitian ini adalah "Apakah Infrastruktur transportasi public di Yogyakarta sudah ramah sama penyandang disabilitas."

\section{Tujuan Penelitian}

Peper ini bertujuan untuk mengetahui tetang infrastruktur transportasi public di kota Yogyakarta apakah sudah ramah dengan penyandang disabilitas, oleh karena itu peneliti ingin mengetahui apakah infrastruktur transportasi public di kota Yogyakarta sudah ramah disabilitas.

\section{Metode Penelitian}

Metode penelitian ini adalah unsur terrpenting didalam melakukan penelitian. Sehingga dengan adanya metode penelitian ini, penulis mampu untuk menjawab permasalahan yang hendak disoroti, Sementara peneliti harus bisa mewujudkan rangkaian pengumpulan data informasi dan peniliti dapat melakukan investigasi pada data yang telah didapatkan tersebut (Suminar, 2016). Seperti kita ketahui untuk melihat setiap metode yang ada tidak lain dan tidak bukan mempunyai sisi kelebihan maupun kekurangan untuk menjawab suatu permasalahan di dalam melakukan penelitian. Oleh karena itu penulis menggunakan metode yang berbeda di dalam melakukan suatu penelitian supaya nantinya bisa saling mengisi dan melengkapi satu sama lainnya.

Penelitian ini adalah penelitian yang bersifat penelitian kualitatif deskriptif. Penelitian kualintatif deskriptif ini lebih menggambarkan tentang bagaimana kejadian, fenomena dan gejala sosial yang ada. Dengan demikian cukup menarik seorang peneliti untuk melakukan penelitian pada fenomena kali ini. Selanjutnya dalam laporan penelitian ini akan berisikan beberapa data untuk memberikan sebuah gambaran kepada pembaca mengenai laporan ini. Laporan yang 
disajikan tersebut dapat berupa foto, catatan atau memo, naskah wawancara dan dokumen-dokumen lainnya.

\section{E. Landasan Teori}

1. Smart city .

Smart city adalah sebuah konsep yang diciptakan untuk efektifitas dan efesiensi dalam penggunaan teknologi, informasi dan komunikasi untuk memberikan pelayanan dan infrastruktur yang diberikan kepada masyarakat (April Insani, 2017). Dengan ini smart city dapat membantu pelayanan public yang lebih efektif dan efesien. Sedangkan Menurut (Perdana, 2017) smart city adalah Konsep memanfaatkan penggunaan teknologi yang canggih berbasis data yang akurat dan terintegritas serta sistem komunikasi informasi layanan terintegritas kepada masyarakat. Sehingga dapat di ketahui masalahmasalah dan dapat dicegah guna mewujudkan kehidupan yang lebih baik, dan berkelangsungan untuk kehidupan di masa depan.

Dengan adanya konsep Smart city diharapkan dapat membantu masyarakat untuk mempermudah mendapat pelayanan dan dapat membantu memecahkan permasalahan yang ada di kota. Menurut (Poernomo, 2015) konsep smart city adalah sebuah pendekatan cerdas dalam membangun kota impian yang bersifat "integralistik atau terintegrasi" untuk mengatasi permasalahan dikota. Sedangkan menurut (Rahman, 2018) konsep smart city adalah penggunaan teknologi informasi dan internet yang lebih luas dalam pelayanan public dan pelayanan pemerintahan.

Inovasi smart city adalah sebuah konsep untuk membantu penyelenggaraan pemerintahan (Darmawan, 2018). Dalam penyelenggaraan pemerintahan yang lebih efektif dan efesien harus ada inovasi-inovasi baru yang diciptakan. Sedangkan menurut (Hidayat, 2015) untuk meningkatkan pelayanan public harus ada inovasiinovasi yang terbarukan. dengan konsisten salah satu kebijakan atau program akan menciptakan dampak besar (Salsabila \& Purnomo, 2017). Sehingga inovasi tersebut dapat terkena langsung dampaknya kepada masyarakat. Didalam konsep smart city kota Yogyakarta ada enam dimensi yaitu smart governance, smart economy, smart mobility, smart living, smart environtment dan smart people. Kota cerdas adalah kota yang bagus transportasi publiknya (Kaledi \& Herwangi, 2019). Dengan hal ini pemerintah kota Yogyakarta sudah meluncurkan transportasi public untuk membantu pelayanan public bagi masyarakatnya

Transportasi public adalah alat transportasi yang disediakan oleh pemerintah untuk mempermudah pelayanan public (Gunartin, 2018). Sehingga dapat membantu masyarakat dalam melakukan kegiatan untuk berpergian. Sedangkan menurut (Faidati \& Khozin, 2018) tranportasi public adalah angkutan penumpang yang dilakukan dengan system sewa atau membayar. Transportasi public yang disediakan oleh pemerintah kota Yogyakarta dengan system membayar, tetapi dengan harga terjangkau karena mendapat subsidi dari pemerintah kota Yogyakarta.
Aplikasi online adalah inovasi masakini untuk mengakses transportasi publik (Sari \& Hayah, 2018). di era semua sudah memanfaatkan teknologi, seharusnya transportasi public juga sudah menerapkan hal yang sama, dengan alasan tidak harus menunggu lama kedatangan alat transportasinya, jadi dapat menghemat waktu dengan adanya teknologi informasi dan komunikasi merubah pandangan atas jarak dan waktu (Rachmawati et al., 2018). Dengan pemanfaatan teknologi informasi dan komunikasi dapat mempermudah dan lebih memakan sedikit waktu.

Moda Transportasi public yang ramah dengan penyandang disabilitas adalah transportasi yang baik (Rusmiari, 2016). Hal ini dapat dilihat pada moda transportasi di kota Yogyakarta, yang masih kurang ramah dengan penyandang disabilitas. Sedangkan menurut (Anggraini, 2016) transportasi yang baik adalah menemukan inovasi-inovasi baru yang lebih inovatif, inovasi yang diberikan harus memiliki keunggulan, manfaat, kesesuaian yang disesuaikan dengan kebutuhan disabilitas. Yang artinya inovasi yang diberikan harus dengan kesesuaian kebutuhan disabilitas.

Singkatnya smart city harus mampu membuat masyarakatnya lebih efektif dan efesien dalam melakukan dan menggunakan pelayanan public, sehingga masyarakat yang tinggal didalamnya lebih merasa senang, nyaman dan aman dalam melalukan aktifitasnya.

\section{Hak-hak Penyandang Difabel}

Dewasa ini, untuk sebutan penyandang cacat tidak lagi di pakai, karena dapat mendeskriminasikan para penyandang difabel. Menurut (Muzwardi, Maritim, \& Ali, 2017), disabilitas adalah seseorang yang mempunyai kendala dalam melakukan aktivitas kesehariannya karena adanya kekurang fisik maupun non-fisik dalam dirinya yang itu berupa pembawaan dari lahir atau karena adanya sebuah peristiwa, tragedy, bencana yang mengakiatkan seseorang mengalami kecacatan dalam anggota tubuhnya. Sedangkan menurut (Suminar, 2015), Penyandang difabilitas dapat diartikan juga sebagai individu yang mempunyai keterbatasan fisik atau mental/intelektual. Keterbatan fisik tidak menjadi masalah bagi kaum difabel, karena mereka juga mampu untuk melakukan hal-hal yang seperti non-difabel lakukan.

Penyandang disabilitas adalah sebutan bagi orangorang yang memiliki kebutuhan khusus (Syafi, 2012). Sedangkan menurut (Jati, 2019), penyandang difabel harus memiliki fasilitas yang khusus yang harus disediakan oleh pemerintah. Seseorang yang mempunyai kebutuhan khusus harus juga pendapat perhatian khusus oleh orang-orang non-difabel. Sehingga menjadikan orang penyandang difabel tidak dipandang sebelah mata. Kebutuhan khusus atau difabel juga dapat diartiakan sebagai orang-orang yang mendapat pelayanan khusus (Husein, 2016). Dengan hal ini, mayarakat yang nondifabel harus mengerti akan keadaan yang dialami oleh difabel. Namun kebanyakan masyarakat masih mendeskriminasi difabel dengan cara-cara yang 
melanggar hak asasi manusia, seperti dijauhi, dihina dan masih banyak lagi.

Hak-hak Disabilitas sudah diatur dalam PerDaIstimewa Yogyakarta No.4 tahun 2012, yaitu perlindungan dan pemenuhan Hak-hak penyandang disabilitas. Dengan hal ini pemerintah Yogyakarta sudah memperhatikan masyarakatnya yang mempunyai kekurangan atau kebutuhan khusus. Hak-hak disabilitas salah satunya adalah hak untuk mendapat mendapat aksebilitas pelayanan transportasi public yang baik.

Pemenuhan hak disabilitas dalam transportasi public adalah mendapat aksebilitas pelayanan yang ramah (Sugi Rahayu et al., 2013). Aksebilitas yang bagus adalah alat kemudahan untuk penyandang difabel dalam mengakses moda transportasi public. Sedangkan menurut (Rahayu \& Dewi, 2013) kemudahan askses transportasi public yang baik dapat memenuhi hak-hak penyandang difabel. Dengan hal ini, penyandang difabel mendapat kesetaraan dalam menggunakan moda transportasi public.

\section{Pembahasan}

Yogyakarta telah menerapkan konsep kota pintar untuk membantu menegakkan sistem pemerintahan, di angkutan umum konsep kota pintar untuk jogja saat ini masih trans. Moda bis transjogja ialah bus dengan konsep aman, terjangkau dan dingin yang beroprasi di kota Yogyakarta. TransJogja adalah program pelaksanaan dari BRT (Bus Rapid Transit) yang diluncurkan oleh Dinas Perhubungan kota Yogyakarta. Transportasi ini muali beroprasi awal bulan maret 2008 . Visi dari transjogja adalah "Aman, Nyaman, Terpercaya, terjangkau, dan ramah lingkungan".

PT Jogja Tugu Trans sebagai pihak yang menggelola bus transjogja, sebagai bentuk manajer organisasi angkutan public perkotaan dan perdesaan untuk wilayah Daerah Istimewa Yogyakarta. Dengan hal ini, semua transportasi public yang ada di Yogyakarta adalah system satu pintu.

fasilitas khusus bagi penyandang cacat untuk akses menggunakan transporatsi public. Halte Bus TransJogja disediakan landai tangga dan rump bagi kaum difabel. rump dimaksudkan hanya untuk cacat, terkhusus untuk kursiroda. Dalam setiap tempat penampungan, halte bis TransJogja terdapat rump seperti yang ditunjukkan pada gammbar di bawah ini.

Gambar 1. Lantai Trans Jogja Bus Stop Landai (dinshub.jogja prov.go.id)

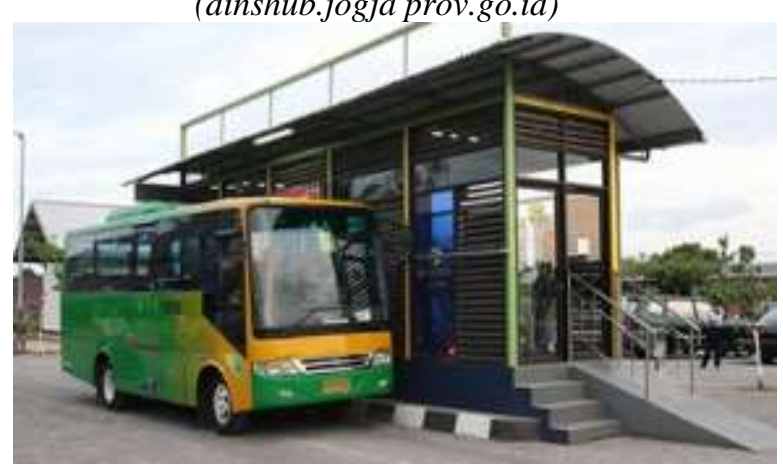

Foto di atas menunjukkan jalan yang telah diperbaiki, tidak curam, berbatasan dengan bangunan atau perpohonan dan juga memiliki pintu masuk yang lebar.

Gambar 2. Trans Jogja Bus Stop lantai Masih curam dan daerah yang kurang (berdiri jogja-Tribunnews.com)

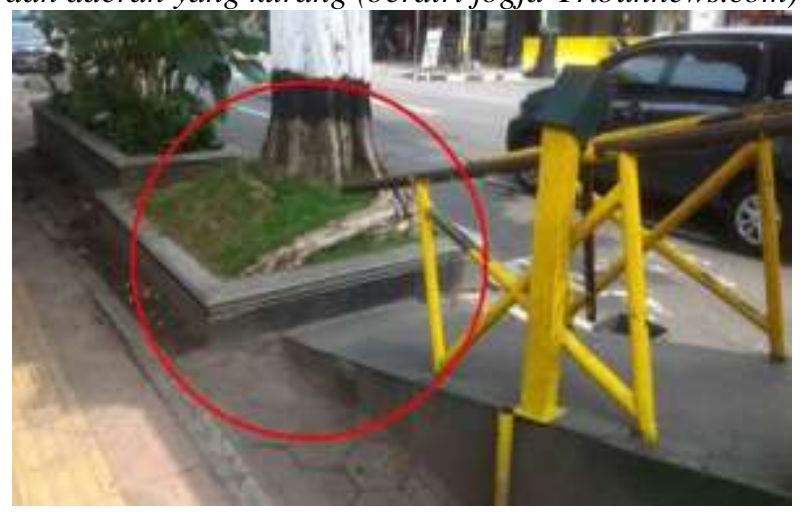

Namun, dalam beberapa tempat penampungan, salah satunya pada gambar nomor 2, menunjukkan bahwa domba jantan itu masih cukup curam dan berbatasan langsung dengan perpohonan, sehingga dapat membahayakan orang-orang cacat. Tidak hanya itu, platform bibir halte bus jarak dan pintu trans jogja bahaya yang cukup besar untuk orang-orang cacat dan membutuhkan petugas bantuan trans Jogja bus untuk naik ke bus.

Hal ini bertentangan dengan pasal 18 UndangUndang Nomor 82016 Tentang Aksesibilitas Penyandang Cacat menjelaskan bahwa dengan Hak Hak Cacat meliputi:

a. Dapatkan akses untuk memanfaatkan fasilitas umum.

b. Mendapatkan akomodasi yang layak sebagai bentuk aksesibilitas bagi individu.

Agar Cacat yang menggunakan kursi roda dapat menggunakan jalan di halte dengan mudah, jalan harus memiliki kemiringan di gedung-gedung publik tidak boleh melebihi7 ', perhitungan kemiringan tidak termasuk awalan atau akhiran landai (ramp trotoar / landing). Sedangkan kemiringan ramp di luar gedung di maksimal $6^{\circ}$.

Untuk memperbaiki itu semua, pemerintah akan memperluas dan memperluas halte bus. Pemberian kerusakan terhadap pelebaran tanah dikonfirmasi oleh Pasal 18 Undang-Undang Nomor 5 Tahun 1960 tentang Peraturan Dasar Pokok Agraria Prinsip, yang menjelaskan bahwa untuk kepentingan umum, termasuk kepentingan bangsa dan Negara serta kepentingan umum dari orang-orang, hak dapat dicabut, dengan memberikan kompensasi yang layak dan dengan cara yang ditetapkan oleh Undang-Undang. Meskipun dalam konteks pembangunan nasional namun Pemerintah harus menghormati hak-hak rakyatnya. Perubahan tersebut terjadi, bahwa untuk pengadaan tanah untuk pelaksanaan pembangunan untuk kepentingan umum oleh Pemerintah bahwa hal itu dapat dilakukan dengan pembelian carajual, pertukaran, atau cara lain yang disepakati oleh para pihak. 
Tujuan untuk pelebaran tanah untuk kepentingan umum berdasarkan Pasal 3 Undang-Undang Nomor 2 Tahun 2012 tentang pelebaran Tanah bagi Pembangunan untuk Kepentingan Umum, yang menjelaskan bahwa Pengadaan Tanah untuk Kepentingan Umum bertujuan untuk menyediakan lahan untuk pelaksanaan pembangunan di memesan untuk meningkatkan kesejahteraan dan kemakmuran bangsa, negara, dan masyarakat sambil memastikan kepentingan pihak yang berhak hukum.

Untuk mendapatkan tanah, Pemerintah harus berkomitmen untuk pengembangan berhenti Pembebasan Lahan. Pembebasan Lahan adalah pembayaran ganti rugi lahan yang akan diambil oleh Pemerintah dan Pemerintah akan memberikan kompensasi sesuai dengan kesepakatan kedua belah pihak.

\section{Kesimpulan}

Berdasarkan kata-kata dari subyek penelitian ini, penulis menyimpulkan bahwa infrastruktur dan bus Trans Jogja masih belum bisa dikatakan ramah untuk orang-orang cacat, karena masih banyak kekurangan yang harus diperbaiki. Pemerintah juga memiliki kesulitan dalam hal pelebaran lahan yang mengakibatkan hak-hak penyandang cacat masih belum dilaksanakan. Sebagian besar halte bus Trans Jogja dan sudah ada yang menyediakan infrastruktur untuk Penyandang Cacat, tetapi tidak dapat dimanfaatkan secara optimal. Standar pengembangan yang belum terpenuhi dan tempat tinggal yang layak bagi Penyandang Cacat

\section{Daftar Pustaka}

Kaledi, S., Dewanti, D., \& Herwangi, Y. Cerdas Mobility Strategi Pengembangan Angkutan Umum yang berbasis di Yogyakarta (Studi Kasus: Transjogja). Wilayah: Jurnal Perencanaan Partisipatif dan Pengembangan Wilayah, 14 (1), 113-123.

Pratiwi, A. 2015. Kesiapan Tingkat Dimensi Surakarta terhadap Cerdas Mobility (Smart Mobility) sebagai bagian dari konsep Cerdas Kota (Smart City).

Insani, PA. 2017. Melalui Kota Responsif mewujudkan Cerdas City. Publisia: Journal of Public Administration Science, 2 (1), 25-31.

Faidat, N., \& Khozin, M. 2018. Analisis Pembangunan Perkotaan Strategi Pintar (Smart City): Studi Kasus Yogyakarta. JIP (Jurnal Ilmu Pemerintahan): Pemerintah dan Politik Studi Regional Studi, 3 (2), 171-180.

Rachmawati, R., Ramadhan, ER, \& Rohmah, AA. 2018. Aplikasi Pintar Provinsi "Jogja Istimewa": Penyediaan Informasi Terpadu dan Pemanfaatan. Geographic Magazine Indonesia, 32 (1), 14-23.

Rahayu, S., \& Dewi, U. 2013. Untuk Layanan Pemenuhan Hak Penyandang Disabilitas Umum di Kota Yogyakarta. Natapraja, 1 (1).

Rahayu, S., Dewi, U., \& Ahdiyana, M. 2013. Pelayanan Publik Transportasi untuk Penyandang Cacat di Yogyakarta. Socia: Jurnal Ilmu Sosial, 10 (2).
Syafi'ie, M. 2014. Untuk pemenuhan Aksesibilitas Penyandang Cacat. Inklusi, 1 (2), 269-308.

Anggraini, AT. 2016. Inovasi Transportasi untuk Pelayanan Publik Penyandang Cacat dengan Difa Yogyakarta City Tour (Doktor disertasi, Fisipol UMY).

Zakiyah, U., Hussein, R., \& Muzwardi, A. 2013. Termasuk Layanan untuk Studi Penyandang Cacat dan Aksesibilitas Pariwisata Fasilitas untuk Cacat di Yogyakarta. Dunia Kesehatan, 169.

Dewi, Putu Nia Rusmiari. 2017. Aksesibilitas untuk Penyandang Cacat di Bus Berhenti dan Trans Jogja di Yogyakarta. .. pp. 1-9. ISSN.

Zakiyah, U., \& Hussein, R. 2017. Pariwisata Ramah Penyandang Cacat. Jurnal Governance dan Kebijakan Publik, 3 (3), 482-505.

Gunartin, G. 2018. Analisis Prestasi Faktor dari Upaya Smart Mobilitas Masalah di Atas Konsep Smart City (Studi Di Kota Selatan Tangerang). Inovasi, 5 (2), 33-41.

Purnomosidi, A. 2017. Konsep Perlindungan Hak Konstitusional Penyandang Cacat di Indonesia. Refleksi Hukum: Jurnal Ilmu Hukum, 1 (2), 161 174.

Jumadi, J. 2018. Efektivitas Peraturan Yogyakarta Wilayah Provinsi Nomor 4 Year 2012 Sesuai Dengan Cacat Hak.

Ristanti, NS 2018. Cerdas Mobility dalam Pembangunan Transportasi Berbasis Aplikasi online di Indonesia. Ruang, 4 (3), 237-246.

Rahman, AZ (2018). Smart City: Peningkatan Pelayanan Publik Inovasi Hari Ini.

Suminar, RE. 2015. Kemudahan Identifikasi Penyandang cacat di Melakukan Gerakan dengan Menggunakan Moda Transportasi. Inklusi, 2 (1), 155-192.

Jati, LP. 2019. Diakses (aksesibilitas bagi Cacat): Sistem Informasi Layanan Aplikasi untuk Penyandang Cacat Fasilitas Umum berbasis WebGIS untuk Dukungan Ramah Cacat Pembangunan Inklusif di Yogyakarta. Prosiding Seminar Nasional Geografi UMS X 2019.

Perdana, MA Politik Pembangunan: Pelaksanaan Smart City. Demokrasi Dan Otonomi Journal, 17 (1), 13 18.

Darmawan, E. 2018. Perkembangan Smart Kota Tanjungpinang. Steering: Jurnal Ilmu Pemerintahan, 2 (2), 60-78.

Salsabila, L., \& Purnomo, EP. 2017, Juli. Membangun dan Pelaksana Good Practices di E-Government (Studi Kasus: Implementasi e-Government antara Korea dan Indonesia). Di ASEAN / Asia Akademik Masyarakat Internasional Conference Proceedings Series. 